\title{
Mobile Government: New Model for E-government in China
}

\author{
Peiyu Wang \\ E-Commerce, Information Management School, Wuhan University, Wuhan 430032, China \\ E-mail: cynthiarain120@163.com
}

\begin{abstract}
This article examines the feasibility of spreading "e" of e-government from solely web-based technology to mobile field after reviewing the development of e-government in China and the present situation of China. Through comparing with traditional web-based e-government and analyzing experiences in both western country and China, a new model GMCC (Government Management \& Call Center) is put forward as an assistant construction of m-government.
\end{abstract}

Keywords: M-government, E-government, GMCC, China

\section{Introduction}

There is not any universally accepted definition of the e-government concept (Halchin, 2004, pp. 406-419., p. 407), thus there are different comprehension of electronic. In the definition of e-government by Means, "e" refers to "electronic means" ( Means and Schneider. 2000, pp.121); In UN \& ASPA, 2002, "e" was defined as "Internet and the World-WideWeb"(2002); and P.T. Jaeger took it as including using other ICTs in addition to the Internet and the Web, such as database, networking, discussion support, multimedia, automation, tracking and tracing, and personal identification technologies (Jaeger, 2003, pp.323-331). In this article, we intentionally take electronic of e-government in a broader way as the integration of Internet, telephones, and call centers.

E-government since its debut has evolved four stages in China (He \& Yang,2006,pp.37):

Initial stage: Office Automation Project (OA). Central and regional governments started to apply OA in mid 80s, 20th century. Government agencies began to use computers for office work and few information centers were established during this period.

Application stage: Informationization of Government Affairs. This period started from the 1990s when the "Tri-Golden Project"-abbreviation for the Golden Bridge, Golden Gateway and Golden Card project-was first sketched to be carried out by the central government aiming at a systematic informationization of government affairs. The main points are laid on infrastructure construction for informationzation and for data and other information exchange for strategically departments.

Developing stage: Government Connection Project(GCP). E-government in late 1990s entered its time of prosperity due to continuous development of net-building technologies and information infrastructure. Early in the year 1998, the first network for information sharing was established in Shenzhen (Liu, Xu and Nie, 2005). In 1999 information centers in more than 40 ministries (departments, agencies) advanced a proposal of the establishment of the "Government Connection Project", which paved the way for further development of e-government.

E-government in China is now in the forth stage which could be termed as e-government Project. The passage of "egovernment Construction Guidelines in China" on July.3rd by National Informationzation Group is a milestone which signals a new step for balanced overall planning and progress of e-government in China.

As Mobile telecommunication tools have always been featuring their affordable prices with strong capabilities of interaction and a user specific service system which all come down to one point of creating a user friendly interface, it's of highly possible for a publication of electronic government administration oriented towards the public on the premise of a welldefined information system from the aspect of mobile telecommunication.

\section{Construction of m-government}

\section{1 basis of m-government realization}

Considering the present situation of China, there are two primary factors that make m-government application feasible:

\subsubsection{Popularization of mobile phones}

Until the time of Dec. 2006, there are up to 137 million netizens and more than 450 million people are enjoying the benefits of Mobil phones nationwide, which is about 3.2846 times the number of the internet users in this country (2007). In other 
reports, $93 \%$ city dwellers and an average of 33.9\% of the whole population are entitled to cell phone services(Song, 2006), among whom 17 million access to the Internet through handset and are accounting for a roughly 12.4 percent ofwhole neitizens (2007). From these statistics, we could see the popularization of mobile infrastructure in China and diversity current of Internet access based on combination of non-stationary and Internet-based terminals.

\subsubsection{Maturity of mobile telecommunication technology}

The amalgamation of mobile telecommunication and mobile computing accelerate the development of mobile technology. Mobile interaction resulting from the application and development of mobile technology makes Ubiquitous Computing and Anytime \& Anywhere connection no more a theory and meanwhile provides a solution for real-time information exchange.

There are mainly 4 types of mobile technologies (Song, 2006):

(1)Radio-based two-way telecommunication (for exclusive or public use) and broadcasting.

(2) Mobile phonic service based on beehive phone, Short Message Service (SMS), Multi-media Messaging Service (MMS) and the Wireless Application Protocol (WAP), General Packet Radio Service(GPRS) and the 3rd Generation(3G).

(3)Services on the availability of mobile apparatus, including laptop, Personal Digital Assistant (PDA), beeper, Radio Frequency Identification(RFID) and Global Positioning System(GPS).

(4) Wireless network like WIFI, WIMAX, blueteeth, etc.

\subsection{Contents of m-government}

\subsubsection{Services based on message}

Short message is the representative. It resembles e-mail on Internet, which acquires low technology while realizes broadest application. Most e-government digital services sprouted on early stage belong to this category, such as message bulletin (water pollution report in Harbin); inward short message (meeting announcement by sending messages in Guang Dong government department); outward short message (feedbacks to customs of its transaction application) (April 4, 2007). Information flowing direction of services based on message transferring could be either unidirectional or di-directional. Government can send messages to all mobile users in an area without knowing exact numbers and mobile users can acquire or customize information by sending message without entangling in complex government organization.

\subsubsection{Services based on Anywhere Internet Access (AIA)}

Anywhere Internet Access (AIA) means the combined application of GPRS, CDMA and the future 3G data transferring technology (Song \& Li, 2006). Some typical examples are the city supervising system in Beijing and other regional systems of police resource management. AIA technology is also useful on occasions of distant data acquirements in environment protection departments, security agencies and dangerous material surveillance department. And WAP, this type of public service should be included since netizens are also given access to government information via GPRS, CDMA which embodies the same function of other e-government applications. These WAP sites have been built by the Hong Kong Special Administrative Region Government and some mainland governing structures.

\subsubsection{Interactive voice response system (IVRS)}

Interactive Voice Response Systems (IVRS) are extensively used for common and structured transactions such as information about ticket reservation, knowing the bank balance, authorizing a transaction, knowing the position of an application or complaint, and authentication of user for secured transactions (Awdhesh and Rajendra, 2007). For example, the Indian Railways provide instant information regarding the confirmation of the tickets, positions of the train by its IVRS (April 4, 2007)query system.

\subsection{Government assistant: Government Management \& Call Center}

In July 2005, Song Gang brought forward "setting up two centers". The one is Supervision Center, which is an independent entity with recruited mobile supervisors and operate a call center as well. The other is Command Center. whose function of coordination is reinforced based in District Integrated Municipal Administration Commission. Responsibility of Mobile Supervisors are as follows: Report to and receive orders from the supervision center; Responsible to inspect and confirm problems in relevant cells; Constant connection to the supervision center through the mobile handset; Position and working status monitored by the supervision center (Song, 2005).

Awdhesh K.Singh and Rajendra Sahu established GCC model (Awdhesh and Rajendra, 2007). Since the interaction of citizens with government is limited and formal, as well as the information overload on Internet, it is much easier for citizens to get information by dialing the Government Call Centers (GCC) and choosing from the standard menu options. Queries can be registered with the GCC and the replies can be sent to the user through SMS, voice mail, or by post. It thus realizes the one-stop service.

In sum, the "two center" model is to realize the supervision of operation process of Mobile government while GCC aims to complement the web-based government information system and provide convenience services for citizen. I conceive to 
combine these two models as a new GMCC (Government Management \& Call Center) model. The figures of only webbased e-government service delivery model(Figure 1) and mobile government combining with GMCC Service Delivery model(Figure 2) are below:

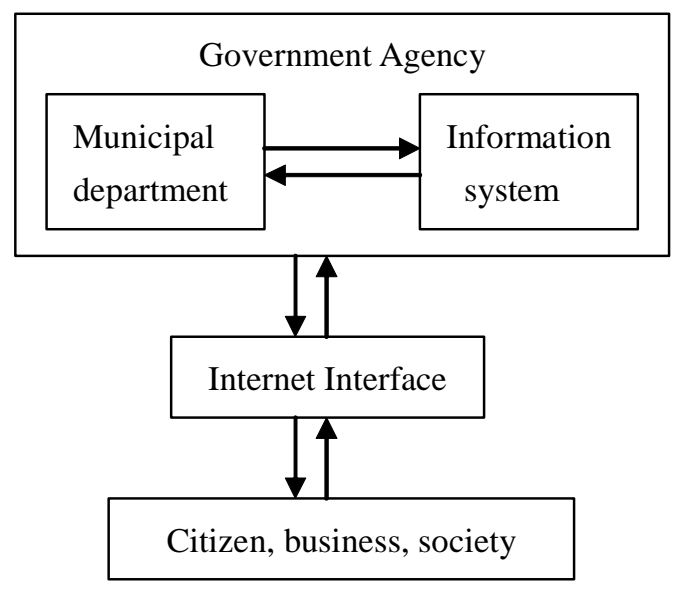

Figure 1. Only web-based e-government service delivery model

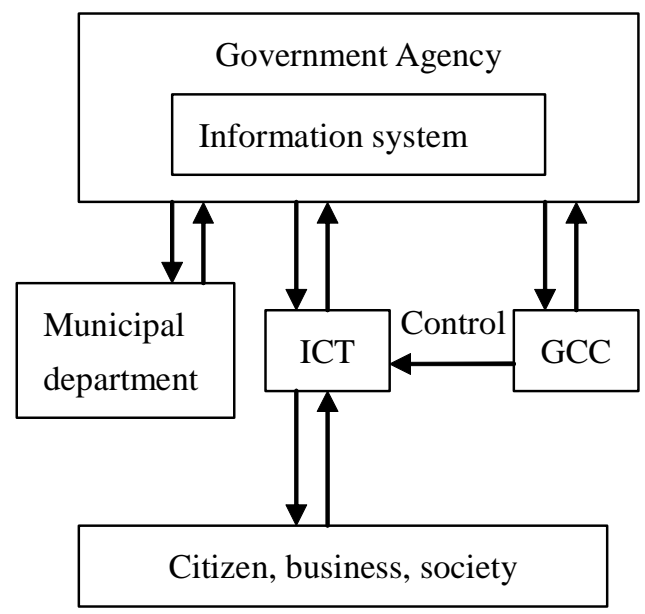

Figure 2. Mobile Government Combining With GMCC Service delivery

\section{Advantages and disadvantages between models based on network and mobile technology}

Firstly, secrecy protections in mobile terminals which have been evolved thorough innovations are comparatively securer than personal computers. But top secrets or extremely important documents are not suggested to be included in wireless transference or processing (Mete, 2007). Secondly, feasibility of large scale documents' one-time transference is not as good as personal computers given the limitations on available storage and processing capability of mobile terminals. However, it could fulfill the requirements of real-time interaction and be handy in relatively urgent situations of immediate approvals or disapprovals, instant feedbacks, etc. Thus, transaction based on mobile technology could be bettered applied on B2C and other daily or ordinary information provision. While technology such as telephone and Internet can enable virtual interaction and build up networks of nodes to transcend the limitation of boundary, the convergence of mobile information and communication technology further enables fluid coordination of work across space and time with an emphasis on 'being local' to provide highly personalized, localized, context aware services to local citizens, thus bridge the virtual and the physical. A shift from Internet based e-government to m-government with a resulting growth in the fluidity of mobile interactions has been showed below: (See Table 1)

Table 1. Social Topology, ICT and Government Service Delivery Model (Song, 2007)

\begin{tabular}{|l|l|l|l|}
\hline Social Typology & Region & Network & Fluidity \\
\hline Characteristics & Boundary & Relation & Variation \& transformation \\
\hline $\begin{array}{l}\text { Typical ICT } \\
\text { Application }\end{array}$ & $\begin{array}{l}\text { Mainframe, local } \\
\text { network, and Pre- } \\
\text { ICT) }\end{array}$ & $\begin{array}{l}\text { Telephone, Internet, e-mail } \\
\text { end user computing }\end{array}$ & $\begin{array}{l}\text { Mobile phone, PDA, Other } \\
\text { convergence technology, Mobile } \\
\text { computing or Ubiquitous computing }\end{array}$ \\
\hline Interaction & $\begin{array}{l}\text { Physical and } \\
\text { collocated }\end{array}$ & $\begin{array}{l}\text { Virtual } \\
\text { Internet Based E-government }\end{array}$ & Mobile Government \\
\hline $\begin{array}{l}\text { Sovernment } \\
\text { Service Delivery }\end{array}$ & Hierarchy & \\
\hline
\end{tabular}

\section{Specific Examples of mobile-government in City of Foshan, China}

During the session of CPPCC(The Chinese People's Political Consultative Conference) and NPC (National People's Congress)of Foshan in Jan. 2007, China Mobile's branch in the city specially designed a series of services including "the Two Sessions Special Area", "Quick E-Access to the Two Sessions" and "Lecture of the Two Sessions" according to the requirements of communication stability and service. At the same time, booklets on how to use mobile service for the meetings are distributed among deputies and committee members. Other information about weather, traffic situations is available to delegates for the successful operation of the meetings through SMS.

A Vehicle Violation and Informing System was invoked in the cooperation between the branch of China Mobile in Foshan and Chancheng's municipal law enforcement department. The project was initiated on May 1st, 2006. It is designed that 
violated parking in restricted areas will be first informed to the driver by short messages asking for a immediate leave before unexpected fines are demanded from the law enforcement department if a so-called "Driver Secretary" service has been subscribed. Since the introduction of the system, traffic management has been improving with better performance of the law enforcement department as we can see.

In police management systems, mobile-government platform enables citizens to inform the police of emergency via short messages when a phone call was not possible. Fire fighters with the help of this system could get more information about accurate positioning and human resource management thus enhancing their abilities in dealing with more severe and dangerous as well as difficult to handle accidents. The completion of Mobile Management on Power Load, which is capable of distant meter-reading and supervising, makes it feasible to mitigate power shortage by way of wireless instruction and live management.

For the time being, more than 20 government departments (among them are taxation bureau, weather station, agriculture administration and land supervising agency, etc) in Foshan have short message service for citizens about personal certificates approving progress.

\section{Conclusion}

China, as the globally largest consumer of mobile telecommunication, will embrace a new information era featured by wireless internet access via mobile terminals, as this trend towards $3 \mathrm{G}$ continues. The popularization of e-government in China on present stage could be achieved by expanding comparatively mature mobile technology. In addition, GMCC established by government could burden functions both on surveiling operations of mobile information service and providing information assistant based on phone.

\section{References}

L.E. Halchin, Electronic government. (2004). Government capability and terrorist resource, Government Information Quarterly, 21, pp. 406-419., p. 407

G. Means and D. Schneider. (2000). Meta-capitalism: The e-business revolution and the design of 21 st century companies and markets, John Wiley \& Sons Inc., New York, p.121

United Nations and American Society for Public Administration (ASPA), 2002 United Nations and American Society for Public Administration (ASPA). Benchmarking e-government: A global perspective. U.N. Publications, New York, NY (2002).

P.T. Jaeger. (2003). The endless wire: E-government as a global phenomenon, Government Information Quarterly 20 (2003) (4), pp. 323-331.

He, Weidong \& Yang, Yang. (2006). E-commerce and e-government construction in network environment. QingHua University publications, Beijing,p.37

Liu, Fengqin, Xu, Bo and Nie, Ruiying. (2005). Research on Development Current Situation and Countermeasure of Egovernment in China. Information Science. Vol.23 No.11

18th report on the development of China's Internet. [Online] Available: http://www.cnnic.cn/html/Dir/2006/07/19/3994.htm (November 2, 2007)

Song, Gang. (2006). Mobile Technology Application in City Management-An illumination of Nomad Project in UK. Municipal Administration and Technology, Beijing City Planning Management Committee. Vol.7, No.3

Song, Gang \& Li, Mingsheng. (2006). Reinventing Public Management by Mobile Government. Office Automation Vol.17

Awdhesh K. Singha and Rajendra Sahub.(2007). Integrating Internet, telephones, and call centers for delivering better quality e-governance to all citizens. Government Information Quarterly. [Online] Available: http://www.sciencedirect. com/ (November 2, 2007)

Indian Railways. Passenger Reservation System. Retrieved October 22, 2006, [Online] Available: http://www.indianrail. gov.in/abcrisprs.html (April 4, 2007)

Song, Gang. (2005). mGov 2005 presentation. [Online]Available: http://www.mgov.cn/ (November 2, 2007).

Mete Yildiz. E-government research: Reviewing the literature, limitations, and ways forward. Government Information Quarterly, [Online] Available: http://www.sciencedirect.com/ (November 2, 2007)

Song, Gang. Transcending e-government: a Case of Mobile Government in Beijing. [Online] Available: http://mobility. grchina.com (November 2, 2007) 